\title{
DEBATE
}

\section{Food contamination with polychlorinated biphenyls and dioxins in Belgium. Effects on the body burden}

N Van Larebeke, A Covaci, P Schepens, L Hens

J Epidemiol Community Health 2002;56:828-830

The core paper of this debate shows that persistent organic pollutant residues of the 12 chemicals targeted for a phase out under the Stockholm Convention are present in almost all categories of food in the US food supply. For dioxins, the study does not use measured data, but is based upon potential dioxin residues in selected food items. Polychlorinated biphenyls are not included in the study. In this paper we discuss selected data of polychlorinated biphenyl and dioxin concentrations in Belgian food. Some of these exposures are chronic, others are attributable to incidents. Both result in high body burdens in Belgium. The paper also compares the current concentrations in food with the recent standards launched by the EU for dioxins in food, and discusses whether these values adequately protect European citizens.

See end of article for authors' affiliations

Correspondence to: Luc Hens, Vrije Universiteit Brussel, Human Ecology Department, Laarbeeklaan 103, B-1090 Brussels, Belgium;

gronsse@meko.vub.ac.be

\section{CHRONIC EXPOSURE}

Background emissions of dioxins in Belgium are high. Although the emissions of primary sources are decreasing, concentrations in the food chain remain among the highest worldwide. In 1995, $1.151 \mathrm{~g}$ I-TEQ of dioxins were emitted in Belgium. ${ }^{1}$ A comparison of dioxin and furan inventories for 15 countries $^{2}$ shows that the per capita emission in Belgium is the second highest after Japan. Sixty per cent of this value is attributable to emissions into the air.

Quantitative data on PCB fluxes for the country to an important diffuse chronic background contamination of these foodstuffs with polychlorinated biphenyls (PCBs).

In a study that aimed at monitoring Belgian chicken and pork intended for export, produced by farms not suspected of being involved in the PCB/dioxin crisis in early 1999, ${ }^{3}$ seven marker PCBs (IUPAC numbers 28, 52, 101, 118, 138, 153, and 180) were analysed in 1850 samples. It was found that in $88 \%$ of the samples concentrations of PCBs were below $50 \mathrm{ng}$ PCBs/g fat, while 12\% of these chicken or pork samples contained more than $50 \mathrm{ng}$ PCBs/g fat. Some $1.2 \%$ of the samples even contained more than $200 \mathrm{ng}$ PCBs/g fat. Two per cent of the samples exceeded the limit set by the Belgian authorities.

\section{ACUTE EXPOSURE}

To these background emissions are added PCBs and dioxins, which are incidentally admixed to as a whole are not available, but some data point the food chain. During the period 1998-2001, three incidents of contamination of the Belgian food chain through PCB/dioxin contamination of animal feed were reported. The most dramatic one occurred in 1999. In January that year, approximately $50 \mathrm{~kg}$ of mineral oil containing PCBs and almost 1 gram of dioxins (the most likely source being discarded transformers originating from a waste recycling centre) was admixed to the fat delivered to 10 animal feed producers. The resulting 500 tons of contaminated animal feed were distributed to poultry farms and, to a lesser extent, also to rabbit, calf, cow, and pig breeding and raising farms, mostly in Belgium, but also in the neighbouring countries. Through the animals the PCBs and dioxins spread over the whole food chain. Chicken, pork, and eggs were the most contaminated products. The authorities only started to act convincingly on the issue after 27 May, when the media made the incident known to the public. One of the actions taken was a large scale monitoring project of PCB and dioxins in food. During the period May to August 1999, 20 491 food samples were analysed. During the period after August 1999, over 40000 samples were analysed as a direct response to the incident. ${ }^{4}$

The highest dioxin concentrations were found in poultry fat and eggs. In $6.5 \%$ of the poultry samples and $8.1 \%$ of the egg samples, concentrations above $200 \mathrm{ng}$ PCBs/g fat were found. For dioxins, concentrations above $2 \mathrm{pg} / \mathrm{g}$ fat were found in $41.9 \%$ of the poultry and $63.6 \%$ of the egg samples. ${ }^{4}$ Of core importance is whether these types of separate incidents have an effect on the body burden of the population. Table 1 shows the results of measurements of three marker PCBs in bloodfat for three groups of Belgian women. One group was monitored before the 1999 incident. The two other groups were studied after the crisis. The data suggest that the crisis caused an important increase in PCB body burden. Although these figures need to be interpreted with caution (for example, because the three groups are not directly comparable), any increase is worrisome as body burdens of PCBs and dioxins of the magnitude found in Belgium have been associated with adverse effects both in animals and in humans. ${ }^{3}$

\section{NEW EU STANDARDS}

As a partial response to the $1999 \mathrm{PCB} /$ dioxin incident in Belgium, the Health and Consumer

Abbreviations: POPs, persistent organic pollutants; PCBs, polychlorinated biphenyls 
Table 1 PCB body burdens in Belgium women before and after the contamination crisis early in 1999

\begin{tabular}{|c|c|c|c|}
\hline & РСВ 138 (ng/g fat) & РСВ 153 (ng/g fat) & PCB 180 (ng/g fat) \\
\hline \multicolumn{4}{|l|}{$1996-1998$} \\
\hline 106 infertile women (aged 24-42) (mean age 31.9) & 69.9 & 94.5 & 72.0 \\
\hline \multicolumn{4}{|l|}{ Second half of 1999} \\
\hline 120 girls (mean age 17.4$)^{10}$ & 75.9 & 101.6 & 55.5 \\
\hline 197 women aged $50-65$ (mean age 58.5$)^{10}$ & 125.4 & 171.1 & 123.1 \\
\hline $\begin{array}{l}\text { Body burden increase in 1999, after correction for age*, as percentage of the } \\
\text { body burden found during 1996-1998 in infertile women }\end{array}$ & 33.6 & 33.5 & 10.2 \\
\hline
\end{tabular}

Table 2 Maximum daily intake, stemming from an average Belgian diet, of PCDD+PCDF, tolerated according to the new European Council regulation (EC) no 2375/2001 of 29 November 2001 (in pg WHO-PCDD/F-TEQ)

\begin{tabular}{|c|c|c|c|c|c|}
\hline Food item & $\begin{array}{l}\text { Average daily } \\
\text { intake in } \\
\text { Belgium (g) }\end{array}$ & $\begin{array}{l}\text { Amount of fat } \\
\text { (g fat } / 100 \mathrm{~g} \\
\text { product)* }\end{array}$ & $\begin{array}{l}\text { Average daily } \\
\text { consumption of fat from } \\
\text { corresponding food item } \\
\text { in Belgium (g) }\end{array}$ & $\begin{array}{l}\text { EU standard (PCDD+PCDF) } \\
\text { (pgWHO-PCDD/F-TEQ/g fat } \\
\text { of product) })^{5}\end{array}$ & $\begin{array}{l}\text { Maximum daily intake of } \\
\text { PCDD+PCDF tolerated } \\
\text { according to new regulation } \\
\text { (pgWHO-PCDD/F-TEQ) }\end{array}$ \\
\hline Bovine meat & 54 & 3.3 & 1.8 & $3 / \mathrm{g}$ fat & 5.4 \\
\hline Pig meat & 56.6 & 10.7 & 6.1 & $1 / \mathrm{g}$ fat & 6.1 \\
\hline Poultry meat & 53 & 9.4 & 5.0 & $2 / \mathrm{g}$ fat & 10 \\
\hline Fish & 30 & & & $4 / \mathrm{g}$ fresh weight & 120 \\
\hline Hen eggs and egg products & 30 & 10.6 & 3.2 & $3 / \mathrm{g}$ fat & 9.6 \\
\hline Milk & 200 & 3.5 & 7 & $3 / \mathrm{g}$ fat & 21 \\
\hline Butter & 20 & 83.4 & 16.7 & $3 / \mathrm{g}$ fat & 50.1 \\
\hline Cheese & 30 & 31.5 & 9.5 & $3 / \mathrm{g}$ fat & 28.5 \\
\hline Edible (mixed) animal fat & 10 & 100 & 10 & $2 / \mathrm{g}$ fat & 20 \\
\hline Edible vegetable oils & 10 & 100 & 10 & $0.75 / \mathrm{g}$ fat & 7.5 \\
\hline Total & & & & & 278.2 \\
\hline
\end{tabular}

*The value for a popular food item of the corresponding type was taken; as to edible oils and edible fats, the intake of which is $20 \mathrm{~g} /$ day, it is assumed that $50 \%$ stems from a vegetable source.

Protection division of the European Commission has established new maximum limits for dioxins in food. ${ }^{5}$ The regulation entered into force on 1 July 2002. Maximum levels range between $0.75 \mathrm{pg}$ WHO-PCDD/F TEQ/g fat (for vegetable oil) to $6 \mathrm{pg} \mathrm{TEQ} / \mathrm{g}$ fat (for liver and derived products). For fish and fishery products, the standard is $4 \mathrm{pg} \mathrm{TEQ} / \mathrm{g}$ fresh weight. Through this expression of concentration per gram fresh weight, the sum of dioxins TEQs in fish will exceed 10 to 20 times the maximum residual limits set for animal meat (expressed per gram fat). These new regulations do not take into account the dioxin-like PCBs for which TEQ values have been set. ${ }^{6}$ These PCBs account respectively for $69 \%$ and between $41 \%$ and $74 \%$ of the total TEQ load of fish ${ }^{7}$ and Belgian meat or dairy products. ${ }^{8}$ Recent measurements show that mean PCDD plus PCDF TEQ levels (not taking into account dioxin-like PCBs) in Belgian meat and dairy products are below the limits set by the new regulations (beef: $1.84 \mathrm{pg}$ TEQ/g fat; pork $0.22 \mathrm{pg}$ TEQ/g fat; chicken $0.35 \mathrm{pg}$ TEQ/g fat; butter $0.80 \mathrm{pg}$ TEQ/g fat; milk $0.34 \mathrm{pg}$ TEQ/g fat). Table 2 provides the data that enable the calculation of the maximum daily intake of dioxins taking into account the new EU standards and an average Belgian diet. The calculation shows that up to $280 \mathrm{pg}$ WHO TEQ per day, corresponding to $4 \mathrm{pg} / \mathrm{kg}$ body weight per day or to $28 \mathrm{pg} / \mathrm{kg}$ body weight per week can be taken in. This is well above the $1 \mathrm{pg} / \mathrm{kg}$ body weight per day that is set by the WHO as a limit for the future, and twice the tolerable weekly intake for dioxins and dioxin-like PCBs set by the Scientific Committee for Food at $14 \mathrm{pg}$ WHO-TEQ/kg body weight. ${ }^{5}$

Standards aimed at regulating maximum residual limits of dioxins in foodstuffs show several limitations, including: the high levels permitted in fish; the lack of standards for dioxinlike PCBs; the intakes they permit, which can be above WHO recommendations; the high levels that are tolerated for pesti- cides (for example, for DDT, the European Council limit is $1000 \mathrm{ng} / \mathrm{g} \mathrm{fat}$ ); the lack of standards for more recently introduced persistant organic pollutants (POPs) such as polybrominated biphenyl ethers (PBDEs); and the current incapability of standards to protect for synergistic effects of these endocrine disrupters.

Much more drastic measures are required to decrease exposure to dioxins, PCBs, and other POPs.

\section{Authors' affiliations}

N Van Larebeke, Department of Radiotherapy, Nuclear Medicine and Experimental Cancerology, Ghent University, Belgium

A Covaci, P Schepens, Toxicological Centre, University of Antwerp, Belgium

L Hens, Human Ecology Department, Vrije Universiteit Brussel, Belgium

\section{REFERENCES}

1 De Fré R, Wevers M. Stofdossier dioxines - eindrapport. MEI-DI-9459. Erembodegem, Belgium: Vlaamse Milieumaatschappii, 1995.

2 UNEP. Dioxin and furan inventories: national and regional emissions of PCDD/PCDF. Geneva: United Nations Environment Programme, 1999.

3 Schepens PJC, Covaci A, Jorens PG, et al. Surprising findings following Belgian food contamination with polychlorobiphenyls and dioxins. Environ Health Perspect 2001;109:101-3.

4 Van Larebeke N, Hens L, Schepens P, et al. The Belgian PCB and dioxin incident of January-June 1999: exposure data and potential impact on health. Environ Health Perspect 2001;109:265-73.

5 EC. European Council regulation (EC) no 2375/2001 of 29 november 2001. O.J. 6 December 2001, L321/1-5.

6 Van den Berg M, Birnbaum LS, Bosveld ATC, et al. Toxic equivalency factors (TEFs) for PCBs, PCDDs and PCDFs for humans and wildlife. Environ Health Perspect 1998;106:775-92.

7 Leonards PEG, Traag WA, de Boer J. Polychlorinated dibenzo-p-dioxins (PCDD), dibenzofurans (PCDF) and biphenyls (PCBs) in Dutch fishery products. Organohalogen Compounds 2001;52:161-4. 
8 Focant J-F, Massart A-C, Eppe G, et al. Levels and trends of PCDD/Fs and CPCBs in Belgian foodstuffs one year after the "dioxin crisis". Organohalogen Compounds 2001;51:243-6.

9 Pauwels A, Covaci A, Weyler J, et al. Comparison of persistent organic pollutant residues in serum and adipose tissue in a female population in Belgium, 1996-1998. Arch Environ Contam Toxicol 2000;39:265-70.
10 Vlietinck $\mathbf{R}$, Schoeters $\mathrm{G}$, Van Loon $\mathrm{H}$, et al. Eindrapport van het onderzoek milieu \& gezondheid: "Ontwikkeling van een concept voor de opvolging en risico-evaluatie van blootstelling aan leefmilieupolluenten en hun effecten op de volksgezondheid in Vlaanderen" 2000

(http://www.wvc.vlaanderen.be/gezondmilieu/onderzoeken/koepel/ index.htm). (last accessed: 19 June 2002)

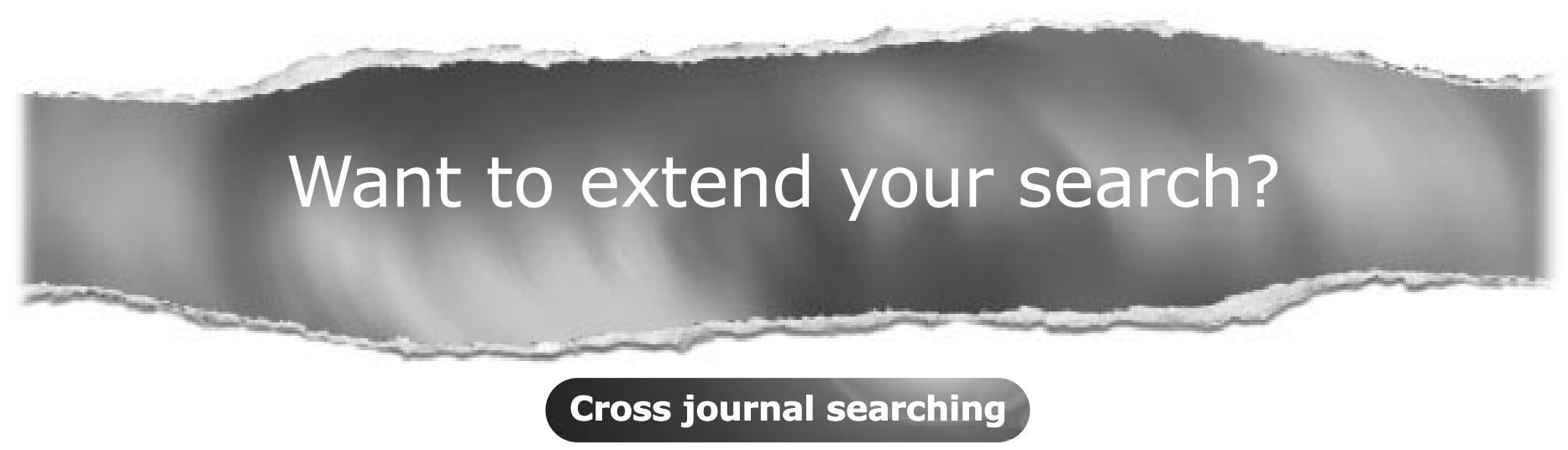

If you can't find what you are looking for in the Journal of Epidemiology and Community Health you can extend your search across many of the more than 200 journals available for selection. You can restrict your search to specific subject areas (eg, clinical medicine, basic research), or select specific journals, or search all available titles.

www.jech.com 